\title{
The origin of farming in the Lower Volga Region
}

\author{
Alexander Vybornov 1 , Pavel Kosintsev 2 and Marianna Kulkova 3 \\ 1 Samara State Academy of Social Sciences and Humanities, Samara, RU \\ vibornov_kin@mail.ru \\ 2 Institute of Plant and Animal Ecology, Urals Branch of the RAS, Ekaterinburg, RU \\ 3 Russian State Pedagogical University, St. Petersburg, RU
}

\begin{abstract}
The paper focuses on the results of archaeological, palaezoological, and radiocarbon analyses of Neolithic and Eneolithic sites in the Northern Caspian and Lower Volga regions. New analyses show that only wild animal species inhabited the territory in the Neolithic. Animals were not domesticated until the Eneolithic period.
\end{abstract}

IZVLEČEK - Članek predstavlja rezultate arheoloških, paleozooloških in radiokarbonskih analiz na neolitskih in eneolitskih najdiščih v severno kaspijski regiji in na področju Spodnje Volge. Rezultati kažejo, da so bile v neolitiku prisotne samo divje živali. Prve udomačene živali se pojavijo v eneolitiku.

KEY WORDS - Neolithic; Lower Volga region; farming; absolute chronology

\section{Introduction}

The Lower Volga region has an extraordinary geographical position, as it borders with Caucasia to the west, Central Asia to the east, and the Caspian region to the south (Fig. 1). Many archaeologists proposed that farming already existed in the Neolithic age in this area. The specific central position of the region was the reason for the close interaction of their inhabitants. It was thought that this allowed for the beginning of cattle domestication in the semi-desert area and in the Volga steppe region already in the Neolithic (Melentiev 1980; Naumov 2002; 2004; Yudin, 2003; 2004; Koltsov, 2004; 2005). However, some archaeologists have shown that only wild animals were present in the Neolithic of Middle Asia (Vinogradov 1981), while others do not agree that the Caucasian artefacts can be attributed to the Neolithic age (Trifonov 2009). Thus the problem of the origin of farming in the Lower Volga region in the Neolithic should be solved by focusing our attention to the analysis of material in this region, not on adjacent territories.

\section{Methods and materials}

Archaeologists distinguish between Neolithic artefacts from three cultural groups in the Lower Volga: Seroglazov (including the sites of Kairshak III, Baibek, and Tentexor) which spread in the Northern Caspian region; Jangar (Jangar and Tubuzgu-Khuduk sites) in the North-Western Caspian region, and Orlov (Varfolomeev, Aglay, Orlovka sites) in the Volga steppe region. On the basis of the analyses of cultural assemblages of these sites, researchers have singled out a number of general distinctive features: the flat-bottomed pottery was made of clay containing silt and clamshells, and was decorated with incised ornaments and geometric motifs; flint tools include blades and abundant geometric microliths. On the basis of the specific artefacts, they were grouped together into the Lower Neolithic Volga culture (Yudin 2004; Koltsov 2005; Vybornov 2008; 2010; 2011; 2013).

Some points need to be discussed: one of them is whether farming evolved in the Neolithic in the re- 
gion or not. This is one of the most important questions, because it determines the definition of the Neolithic age; at the same time, this is one of the most difficult problems, as it cannot be solved only in terms of archaeology; an interdisciplinary study needs to be carried out. In order to study the Neolithic assemblages of the Lower Volga, it is essential to make a thorough and consistent assessment of the material and analyse the context of each artefact.

Archaeologists face certain methodological problems when working on early cattle breeding in the region considered, as this work is based on differentiating domestic from wild animal bones. Wild animal species lived in the area in the Holocene: auroch (Bos primigenius), wild boar (Sus scrofa), and tarpan (Equus ferus; wild horse). These species were the ancestors of domestic animals:

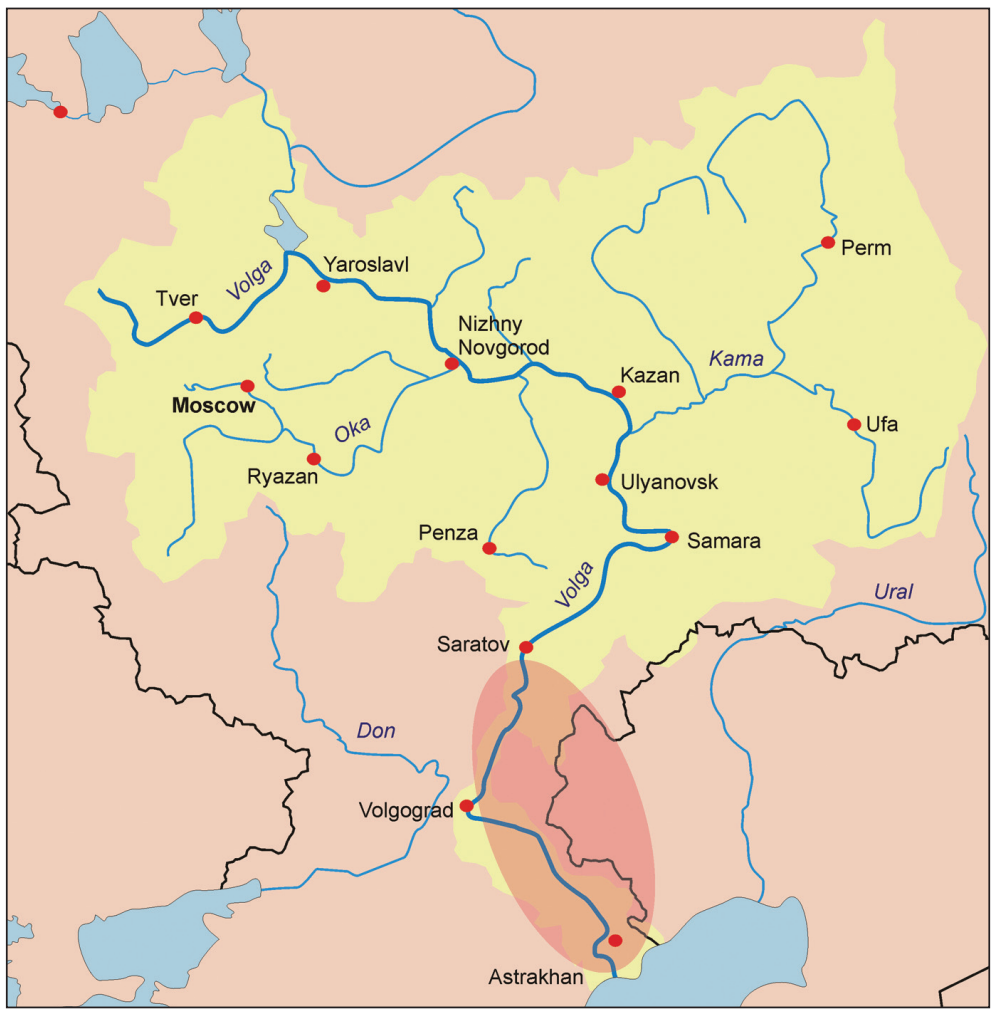

Fig. 1. Map of the Lower Volga region. cattle (Bos taurus), the domestic pig (Sus scrofa domestica) and the horse (Equus caballus). The morphological characteristics of the bones of wild and domestic animals are very similar, but they vary in size.

The size of auroch and wild boar declined after domestication (Tsalkin 1970.164-165, 80-182); however, in the Neolithic period, cattle bones were as big as those of aurochs (Tsalkin 1970.60-62). Bovid bones became smaller after domestication, and, ultimately, domestic male cattle bones came to be the same size as those of female wild aurochs. Another problem is connected with differentiating between domestic and wild horse bones. Since domestication did not influence bone size, it is impossible to know whether animal bones should be attributed to horses or tarpans. The size of wild boar changed very rapidly after domestication, and pig bones in the Neolithic were considerably smaller than those of wild boar (Tsalkin 1970.180-182). Wild sheep (Ovis aries) and goat (Capra hircus) never inhabited the region, so only domestic ones appeared.

Bone fragments from six Neolithic (Tab. 1) and five Eneolithic (Tab. 2) settlements were analysed in the present study. The bones from the site of Jangar were identified by Vladimir P. Danilchenko and Irina V. Kirillova. The bone descriptions from Tentexor I, Kurpezhe-Molla, and Karakhuduk I are already published (Kuzmina 1988.175). The bone collection is kept in the Zoology Institute of the Russian Academy of Sciences (St. Petersburg) and was reanalysed by one of the authors of this paper. The results (Tab. 1) were different from the previously published data (Kuzmina 1988.175). The bone collection from Varfolomeev site was also analysed (Gasilin et al. 2008.27) and our results varied from previously published information (Yudin 2004.195).

The bones found at the sites were kitchen waste, so most of the bone find were fragmented. Bone mesurements were taken using standard methods (Driesch 1976.40-93). The identification of aurochs and cattle bones was made on the basis of their dimensions; large bones were identified as aurochs and small ones as cattle. The dimensions of auroch bones from European Holocene sites (Boessnek 1957, cited in Tsalkin 1970.52-57; Degerbøl 1942 cited in Tsalkin 1970.52-57; Gasilin et al. 2008.70; Kobryn, Lasota-Moskalewska 1989.73; Requate 1957, cited in Tsalkin 1970.52-57) and Kazakhstan (Gayduchenko 1998) are listed in Table 3. The dimensions of cattle from Neolithic and Eneolithic sites in Western Europe are also shown in the table (Kobryn, Lasota-Moskalewska 1989.73; Petrenko 2000.10-11; Vörös 1980.59; Zalkin 1970.52-57). As shown in Table 3, the size of the Neolithic bones is the same as the auroch bones and bigger than the largest do- 


\begin{tabular}{|c|c|c|c|c|c|c|}
\hline & \multicolumn{6}{|c|}{ Cultures } \\
\hline & \multicolumn{3}{|c|}{ Seroglazovskaya } & \multirow{2}{*}{\begin{tabular}{|c|} 
Jangarskaya \\
Jangar
\end{tabular}} & \multicolumn{2}{|c|}{ Orlovskaya } \\
\hline & Kairshak III & Baibek & Tentexor I & & Varfolomeevka & Algay \\
\hline Sheep - Ovis aries & & & $1 / 1$ & & & \\
\hline Wild ass - Equus hemionus & $619 / 12$ & $1891 / 91$ & $1290 / 40$ & $615 / 28$ & $714 / 19$ & $266 / 37$ \\
\hline Saiga antelope - Saiga tatarica & $19 / 3$ & $48 / 7$ & $79 / 9$ & $2006 / 103$ & $423 / 17$ & $297 / 21$ \\
\hline Aurochs - Bos primigenius & $1 / 1$ & $4 / 2$ & $79 / 4$ & $55 / 9$ & $684 / 11$ & $630 / 31$ \\
\hline Red deer - Cervus elaphus & $56 / 5$ & $17 / 5$ & $3 / 1$ & $14 / 6$ & $8 / 2$ & $4 / 2$ \\
\hline Tarpan - Equus ferus & & & $32 / 2$ & $298 / 15$ & $724 / 21$ & $357 / 38$ \\
\hline Boar - Sus scrofa & & $5 / 2$ & & $2 / 2$ & $18 / 4$ & $3 / 2$ \\
\hline Dog - Canis familiares & + & $8 / 2$ & & & $43 / 5$ & $6 / 3$ \\
\hline Hare - Lepus europaeus & $1 / 1$ & $1 / 1$ & & $1 / 1$ & & $1 / 1$ \\
\hline Fox - Vulpes vulpes & $3 / 1$ & $12 / 4$ & & $10 / 3$ & $18 / 4$ & \\
\hline Wolf - Canis lupus & $8 / 2$ & $11 / 4$ & + & & $41 / 7$ & \\
\hline Corsac fox - Vulpes corsac & $2 / 1$ & $35 / 8$ & & $57 / 7$ & $13 / 4$ & \\
\hline Gazelle - Gazella sp. & & & & $118 / 24$ & & \\
\hline Tolai hare - Lepus tolai & & $2 / 1$ & & & & \\
\hline European badger - Meles meles & & & & & $1 / 1$ & \\
\hline Birds - Aves & 1 & 1 & & & 21 & \\
\hline Tortoise - Chelonia & & & & & 2 & \\
\hline Fish - Pisces & & 40 & & & 6 & 2 \\
\hline
\end{tabular}

\section{Tab. 1. The species composition and the numbers of vertebrate bone remains.}

mestic cattle bones. For example, the M3 tooth length from the Neolithic sites changed from 44.7 to $47.1 \mathrm{~mm}$; the European aurochs from 41.0 to $54.0 \mathrm{~mm}$; the Kazakhstan aurochs from 39.1 to $53.4 \mathrm{~mm}$, and the Khvalinskiy cattle from the Volga region from 36.0 to $38.0 \mathrm{~mm}$. Only the biggest teeth from the sites of the Linear Pottery, Boyan, Gumelnitsa, and Maykopskiy cultures were of the same size, but this is because auroch bones were found with cattle bones at the same sites (Tsalkin1970.50-53). The same results were obtained by comparing the length of ankle bones (Tab. 3). Based on this information, we identified all Bos bones from Neolithic sites as aurochs.

\section{Discussion}

Jangar is the first site at which archaeologists supposed farming appeared in the region. Three cultural layers have been distinguished which included the bones of the saiga (Saiga tatarica), the onager (Equus hemionus), the horse, and cattle (Bos sp.). We believe that in the ratio domesticated to wild animals, the number of the first group increased, while the number of the second was reduced (Koltsov 2004.134). However, the statistics in the published table do not show such a tendency. Petr M. Koltsov (2005.19-20) states that materials which evidence a step in the evolution in people's lives

\begin{tabular}{|c|c|c|c|c|c|}
\hline & \multicolumn{5}{|c|}{ Cultures } \\
\hline & \multicolumn{2}{|c|}{ Caspian } & \multicolumn{3}{|c|}{ Khvalynskaya } \\
\hline & Kurpezhe-Molla & Oroshaemoye I & Karakhuduk I & KairshakVI & Kombak-Te \\
\hline $\begin{array}{l}\text { Sheep - Ovis aries } \\
\text { and goat - Capra hircus }\end{array}$ & $120 / 8$ & $8 / 3$ & $152 / 10$ & $168 / 24$ & $94 / 47$ \\
\hline Cattle - Bos taurus & & & $18 / 2$ & $22 / 2$ & $1 / 1$ \\
\hline Wild ass - Equus hemionus & $78 / 5$ & $2 / 1$ & $17 / 2$ & $21 / 2$ & $25 / 3$ \\
\hline Saiga antelope - Saiga tatarica & $154 / 5^{*}$ & $13 / 4$ & $7 / 2$ & $13 / 2$ & $3 / 1$ \\
\hline Tarpan - Equus ferus & $1 / 1$ & $10 / 3$ & & $19 / 2$ & \\
\hline Red deer - Cervus elaphus & $26 / 2$ & & & $4 / 1$ & $5 / 2$ \\
\hline Aurochs - Bos primigenius & $8 / 1$ & $17 / 4$ & $3 / 1$ & & \\
\hline Corsac fox - Vulpes corsac & & & $10 / 1$ & & $3 / 1$ \\
\hline Boar - Sus scrofa & & $2 / 1$ & & & \\
\hline Wolf - Canis lupus & $9 / 2$ & & & & \\
\hline Dog - Canis familiares & & & & $4 / 2$ & \\
\hline
\end{tabular}

Tab. 2. The species composition and the numbers of vertebrate bone remains. 


\begin{tabular}{|c|c|c|}
\hline Sites, culture & Date & Measurements [N-Min-Max-M] \\
\hline \multicolumn{3}{|c|}{$\mathrm{L}_{3}$} \\
\hline Algay, Orlov & $6800 \pm 40$, Neolithic & $6-34.4-38.7-36.6$ \\
\hline \multicolumn{3}{|c|}{ L m3 } \\
\hline$\overline{\text { Aurochs (Denmark) }{ }^{1}}$ & Holocene & $?-46.0-53.3-?$ \\
\hline Aurochs (Germany) ${ }^{2}$ & Holocene & $?-44.0-54.0-?$ \\
\hline Aurochs (Germany) ${ }^{3}$ & Holocene & $?-41.0-44.5-?$ \\
\hline Kozhai 14, Tersek culture & mid. of $4^{\text {th }}$ mil. BC, Eneolithic & $9-39.1-48.1-44.8$ \\
\hline Kumkeshu 14, Tersek culture & mid. of $4^{\text {th }}$ mil. BC, Eneolithic & $28-41.5-53.4-46.2$ \\
\hline Kaindy $3^{4}$, Tersek culture & mid. of $4^{\text {th }}$ mil. BC, Eneolithic & $6-43.2-45.4-44.2$ \\
\hline Algay, Orlov & $6800 \pm 40$, Neolithic & $3-44.7-45.1-44.9$ \\
\hline Oroshaemoel, Caspian & $5667 \pm 100$, Eneolithic & 47.1 \\
\hline Cultures of Linear Band Pottery and Boyan 5 & mid. of $5^{\text {th }}$ mil. BC, Neolithic & $41-34,1-46,0-38,7$ \\
\hline Gumelnitsa Culture 5 & $7^{\text {st }}$ half of $5^{\text {th }}$ mil. BC, Neolithic & $41-34,1-46,0-38,8$ \\
\hline Maykopskiy Culture5 & end of $5^{\text {th }}$ mil. BC, Eneolithic & $41-34,1-46,0-39,8$ \\
\hline I Khvalinskiy site6, Khvalinskiy culture & beginning of $5^{\text {th }}$ mil. BC, Eneolithic & $6-36.0-38,0-37,1$ \\
\hline \multicolumn{3}{|c|}{ GLI astragalus } \\
\hline Aurochs (Eastern Europe) 5 & Holocene & $125-74.1-95.0-83.2$ \\
\hline Aurochs (Poland) ${ }^{7}$ & Holocene & $84-70.0-98.0-?$ \\
\hline Algay & $6800 \pm 40$ & $3-82.7-89.6-86.4$ \\
\hline Ten-Teksorl, Seroglazov & $6695 \pm 40 ; 6540 \pm 100$ & 83.0 \\
\hline Varfolomeevka8, Orlov & $7^{\text {st }}$ half of $6^{\text {th }}$ mil. BC, Neolithic & $32-71.3-91.9-82.6$ \\
\hline Karakhuduk I, Khvalinskiy culture & beginning of $5^{\text {th }}$ mil. BC, Eneolithic & 74.0 \\
\hline Kairshak VI, Khvalinskiy culture & beginning of $5^{\text {th }}$ mil. BC, Eneolithic & 74.3 \\
\hline Körös ${ }^{9}$ culture & $6^{\text {th }}$ millennium BC, Neolithic & $18-58-76-69.7$ \\
\hline Early Tripolye & $2^{\text {nd }}$ half of $5^{\text {th }}$ mil. BC, Neolithic & $20-62.0-96.0-77.2$ \\
\hline Gumelnitsa Culture5 & $7^{\text {st }}$ half of $5^{\text {th }}$ mil. BC, Neolithic & $50-59.0-93.0-71.9$ \\
\hline Maykopskiy Culture5 & end of $5^{\text {th }}$ mil. BC, Eneolithic & $73-60.0-86.0-72.2$ \\
\hline Neolithic, cattle7 & & $132-54.0-78.0-?$ \\
\hline 1 Degerbøl 1942 (cited in Tsalkin 1970) & 4 Gayduchenko 1998 & 7 Kobryn, Lasota-Moskalewska 1989 \\
\hline 2 Requate 1957 (cited in Tsalkin 1970) & 5 Tsalkin 1970 & 8 Gasilin et al. 2008 \\
\hline 3 Boessnek 1957 (cited in Tsalkin 1970) & 6 Petrenko 2000 & 9 Vörös 1980 \\
\hline
\end{tabular}

Tab. 3. Bone dimensions (in mm) of auroch (Bos primigenius) and cattle (Bos taurus).

were found in the upper layer of the site, because auroch, tarpan, and sheep bones similar to domestic species were collected. This means that the tarpan and auroch bones from the lower and middle layers were not domesticated. The sheep bones from the upper layer are not mentioned in the table. At the same time, Koltsov (2005.316-321) reports that Neolithic ceramics and flint were mixed with those of the Eneolithic in the same layer, which is why archaeologists identified the appearance of domestic animal bones with the Eneolithic materials (Vybornov 2008). This concerns only sheep bones, because it has not been proved that other bones from the upper layers of Jangar could be attributed to domesticated animals. Therefore, the suggestion that the context provides the evidence of Neolithic farming in the steppe (Koltsov 2004.137) cannot be regarded as realistic. According to the recently obtained radiocarbon dates, the lower and middle layers at the site date to the first quarter of the $6^{\text {th }}$, and the upper layer to the middle of the $6^{\text {th }}$ millennium calBC (Vybornov et al. 2013). The upper layer that contains Eneolithic material and sheep bones was dated to the beginning of the $5^{\text {th }}$ millennium BC (Koltsov 2004). Varfolomeev is another site with a well-preserved cultural layer. It was differentiated into several levels: the lower level (layer 3) was attributed to the middle Neolithic; the middle layers (2B and 2A) were attributed to the late Neolithic, and an upper layer was attributed to the early Eneolithic age (Yudin 2004). On the basis of sheep bones, Yudin dated the appearance of farming to the second stage of the late Neolithic (layer 2A; Yudin 2003). However, we should note the author's statement that houses were built into the ground in the lower levels of the site (Yudin 2004.18). This means that the deposits of the lower layers could have included mixed artefacts as well as bone fragments. In addition, taphonomic processes may have caused the intrusion of auroch and tarpan bones from the upper layer 20 to layer 4 bellow (Yudin 2004. 195). In Koltsov's opinion, the increasing quantity of these bones indicates that they were domesticated, but the example of the Varfolomeev site dis- 


\begin{tabular}{|c|c|c|}
\hline Sites, culture & Date & Measurements [N-Min-Max-M] \\
\hline \multicolumn{3}{|c|}{ GLI astragalus } \\
\hline Ten-Teksorl, Seroglazov & $6695 \pm 40 ; 6540 \pm 100$, Neolithic & 31.6 \\
\hline Oroshaemoe I, Caspian & $5667 \pm 100$, Neolithic & $2-29.4-32.0-30.7$ \\
\hline Kuperzhe-Molla, Caspian & endof $6^{\text {th }}$ mil. BC, Neolithic & $9-28.6-31.9-30.4$ \\
\hline Karakhuduk I, Khvalinskiy & beginning of $5^{\text {th }}$ mil. BC, Neolithic & $5-28.7-33.0-30.7$ \\
\hline KairshakVI, Khvalinskiy & beginning of $4^{\text {th }}$ mil. BC, Eneolithic & $13-27.8-37.0-30.2$ \\
\hline Kombak-Te, Khvalinskiy & Eneolithic & $57-25.9-33.5-29.9$ \\
\hline I Khvalinskiy site ${ }^{1}$, Khvalinskiyculture & beginningof $5^{\text {th }}$ mil. BC, Eneolithic & $62-27.0-32.0-29.2$ \\
\hline II Khvalinskiy site², Khvalinskiyculture & beginningof $5^{\text {th }}$ mil. BC, Eneolithic & $28-26.0-33.0-28.8$ \\
\hline \multicolumn{3}{|c|}{ GL metacarpale III+IV } \\
\hline KairshakVI, Khvalinskiy & beginning of $5^{\text {th }}$ mil. BC, Eneolithic & 153.0 \\
\hline I Khvalinskiy site ${ }^{1}$, Khvalinskiyculture & beginning of $5^{\text {th }}$ mil. BC, Eneolithic & $2-158-159-158.5$ \\
\hline \multicolumn{3}{|c|}{ GL metatarsale III+IV } \\
\hline I Khvalinskiy site ${ }^{1}$, Khvalinskiyculture & \multirow[t]{2}{*}{ beginning of $5^{\text {th }}$ mil. BC, Eneolithic } & \multirow[t]{2}{*}{$2-164-172-168$} \\
\hline 1 Petrenko 2000 & & \\
\hline
\end{tabular}

\section{Tab. 4. Bone dimensions (in mm) of sheep (Ovis aries).}

proves the idea. Significantly, the number of saiga bones fell from 19 to 5 units in the layers mentioned. There was no precise diagnostic data proving horse domestication at this site. Concerning sheep bones, according to the published table (Yudin 2004), three animals were found in the upper layer (layer 1), but the level relates to the Eneolithic period. According to the radiocarbon dates, the late Neolithic materials in layer $2 \mathrm{~B}$ date to the first quarter of the $6^{\text {th }}$ millennium calBC, and layer $2 \mathrm{~A}$ was attributed to the second quarter of the $6^{\text {th }}$ millennium cal BC (Vybornov et al. 2013). The same dates were obtained from the corresponding layers of Jangar. The dates of the Varfolomeevskaya site upper (Eneolithic) layer correspond to the dates of the upper layer of Jangar, the beginning of the $5^{\text {th }}$ millennium calBC. During the second analysis of the Varfolomeevskaya bones, archaeologists failed to identify sheep bones in the upper and middle $2 \mathrm{~A}$ layers (Gasilin et al. 2008.27).

The Lower Volga Neolithic site at Algay was discovered and analysed in 2014 (Vybornov et al. 2015). The cultural layer contains artefacts of the Orlov Neolithic culture only. According to the radiocarbon dates the site is embedded into the first half of the $6^{\text {th }}$ millennium calBC. Only wild animal species were identified at the site such as auroch, tarpan, onager, saiga, and dog bones that predominate (see Tab. 1). Only the dog was definitely domesticated.

Animal bones have also been discovered at the main Neolithic sites of the Northern Caspian region, at Kairshak III (Kozin 2004) and Tentexor I (Kuzmina 1988). The Kairshak sites were attributed to the early Neolithic and dated from the turn of the first and second quarters of the 7 th millennium calBC to the turn of the $7^{\text {th }}$ and $6^{\text {th }}$ millennium calBC ( $\mathrm{Vy}$ bornov et al. 2013; Vybornov 2014). Onager, red deer, saiga, wolf, corsac fox, hare, and dog bones were identified at the sites. Late Neolithic sites such as Tentexor date between the beginning and middle of the $6^{\text {th }}$ millennium calBC (Vybornov et al. 2013). In Tentexor I, onager, saiga, aurochs, wolf, and horse bones were found. Irina E. Kuzmina did not believe they were domesticated, and dated the domestication process to the later Eneolithic culture (Kuzmina 1988.182).

The new Neolithic site at Baibek in the Northern Caspian region, excavated in 2013-2014, is attributed to the Seroglazov culture (Grechkina et al. 2014). The cultural layer was found in situ and contained artefacts attributed to the early Neolithic only. Bones of onager, saiga, red deer, wolf, corsac fox, wild boar, auroch, fox, and hare (Tab. 1) were identified here. Dog was the only domesticated animal identified. The site was dated to between the end of the $7^{\text {th }}$ and the beginning of the $6^{\text {th }}$ millennium calBC (Vybornov 2014).

As we have discussed above, the analyses of Neolithic assemblages of the Lower Volga region showed the presence of wild animal species only. The dog is the only animal which can be regarded as definitely domestic if we consider the timeframe of the early Neolithic.

The bones of domestic sheep were identified in the territory of the Khvalinskiy culture in the middle 


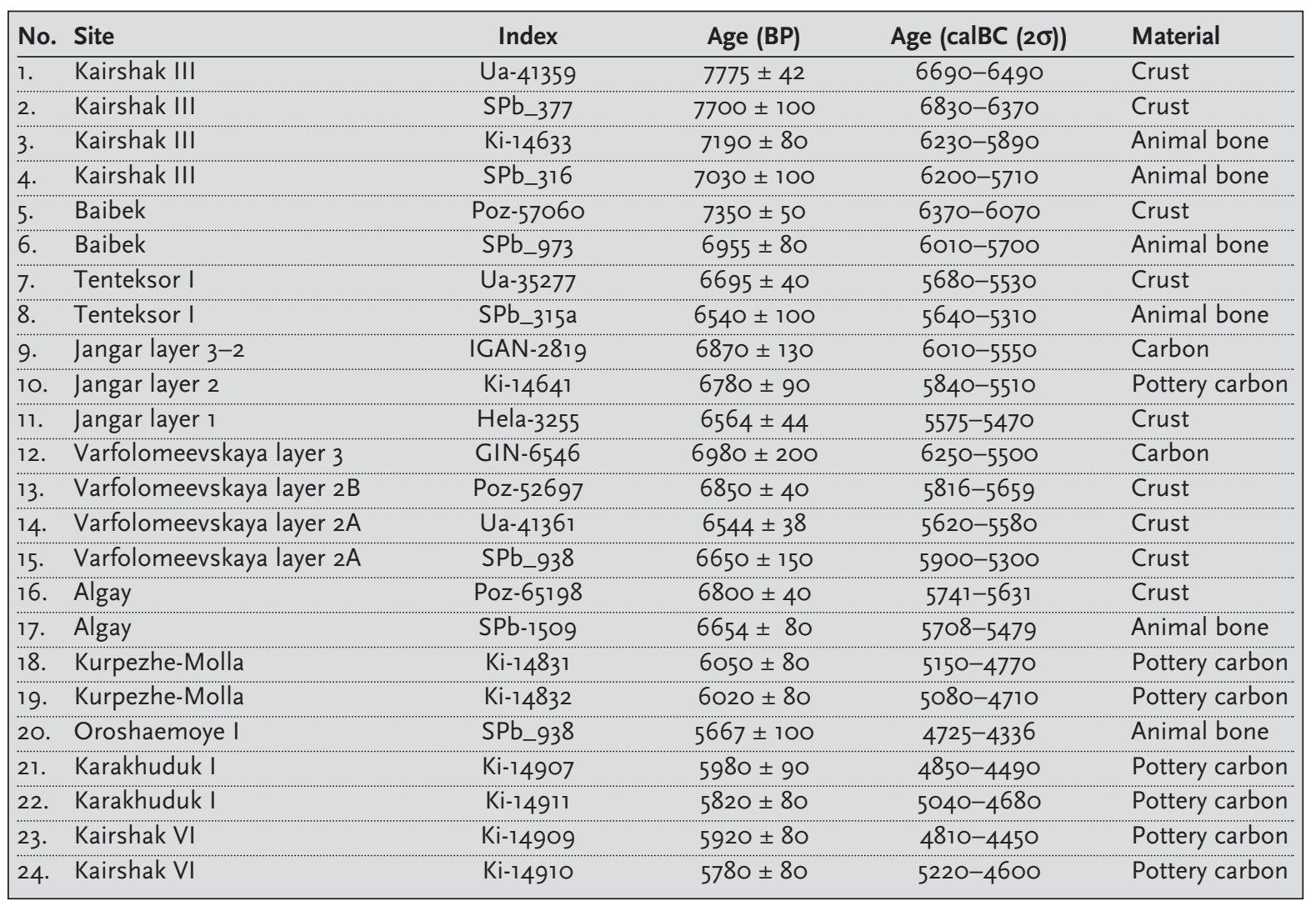

Tab. 5. Radiocarbon dates for Neo-Eneolithic sites of the Lower Volga region.

Eneolithic (Kuzmina 1988). The sites of the culture date to the first part of $5^{\text {th }}$ millennium calBC (Morgunova et al. 2010). A few Caspian culture sites of the late Neolithic/early Eneolithic date to the second part of $6^{\text {th }}$ millennium calBC.

At the Northern Caspian site of Kurpezhe-molla (Barynkin, Vasylyev 1985) only wild animal bones were identified through preliminary analysis, including saiga, onager, and auroch (Kuzmina 1988.175). However, after further study, we obtained different information showing the presence of sheep and goat (see Tab. 2). It is possible that they relate to a small quantity of later materials from the middle Eneolithic period of the Khvalinskiy culture. The site dates to the end of the $6^{\text {th }}$ millennium calBC (Vybornov 2008).

Until recently, no Eneolithic sites with animal bones have been found in the Volga steppe region until recently. The situation changed in 2014, when the site Oroshaemoye I was analysed and a cultural layer found in situ with artefacts related to the Caspian culture. According to the archaeozoological results, the bones belong to saiga, auroch, tarpan, wild boar, onager and domesticated sheep and goat (Tab. 2). Thus it is the only site which could be attributed to the transition from the Neolithic to the Eneolithic where the bones of domestic animals may be observed. According to the radiocarbon analysis of animal bones, the site dates to the second quarter of the $5^{\text {th }}$ millennium calBC. Similar dates were obtained in analyses of other sites of the culture in the Volga-Ural interfluve (Morgunova et al. 2010). If we consider the sites of the Khvalinskiy culture which include undisturbed layers, such as Kara-Khuduk (Barynkin, Vasylyev 1988) and Kairshak VI (Barynkin 1989), they yielded both sheep as well as cattle bones (Tab. 2).

As mentioned above, no wild species of sheep or goat inhabited the territory in question; all bone finds are from domestic animals. The earliest example of domesticated sheep, an ankle bone, was discovered in Tentexor I and dated to the first half of the $5^{\text {th }}$ millennium calBC (Tab. 1). It is now unclear whether it dates to the Neolithic or to a later period. However, it is possible to answer this question by radiocarbon dating. As already discussed, all the other Neolithic sites in the region lacked bones of domestic animals other than dog bones.

Confirmed bones of domestic animals appeared at sites of the Caspian culture. Sheep bones, which 
comprise the majority of the bone assemblage, and rare goat bones were discovered at sites Oroshaemoye I and Kurpezhe-Molla (Tab. 2). The sheep bones were large; their height, calculated on the basis of ankle bones (Teichert 1975.63), varied between $64-72 \mathrm{~cm}$, with an average of $69 \mathrm{~cm}$. This is suggested by the size of metapodia (see Tab. 4). No cattle bones were found at sites of this culture. These results probably reflect limited bone sampling (Tab. 2). At Kurpezhe-Molla, sheep and goat bones represent $47 \%$ of wild and domestic ungulate bones, which shows that these species played a very important role in nutrition.

Sheep and goats appeared together with cattle for the first time at sites of the Khvalinskiy culture (Tab. 2). In all areas, sheep (again comprising the majority) and goat bones predominated. Cattle were large, according to the analysis of ankle bones (Tsalkin 1970.162), as their average calculated height was $138 \mathrm{~cm}$. The sheep were also large, according to the analysis of ankle bone (Teichert 1975.63); their height varied from $59-84 \mathrm{~cm}$, with an average of $68 \mathrm{~cm}$. In the areas of the Khvalinskiy culture, sheep and goat bones were more numerous than ungulate hooves (Tab. 2) and comprised between $68-77 \%$, while cattle made up from 1-9\% and ungulates from 14-26\%. Cattle breeding was of great importance in the Khvalinskiy culture, which is attested by the great abundance of cattle, sheep, and goat bones (Bogatkina 2010.400-402; Petrenko 2000.13-14).

Equus remains were discovered on the territory of all cultures (Tabs. 1, 2). We suppose the horse was domesticated later than cattle, sheep, goats, and pigs. The domestic horse appeared when people already had domesticated ungulates, which is why equid bones are from wild species, such as tarpan. It is more difficult to identify the equid bones from Eneolithic sites, since there were fewer equid re- mains, and other domestic ungulates were also found (Tab. 2). Equid bones were collected at Khvalinskiy culture sites, at Khvalinskiy I and Khvalinskiy II (Bogatkina 2010.400-402; Petrenko 2000.13-14), where both wild and domestic animals could have been used in mortuary rites. So the use of equid bones in such ceremonies did not indicate that people had domestic horses. In our opinion, the bones from the Khvalinskiy culture sites should be attributed to wild species of horse, possibly tarpan.

\section{Conclusion}

The analysis of faunal remains found at sites with undisturbed Neolithic layers in the Lower Volga region suggests that only wild animals were exploited. According to the radiocarbon dates, the Neolithic in the area dates to between the second quarter of the $7^{\text {th }}$ and the middle of the $6^{\text {th }}$ millennium calBC. The only domestic animal present in this time period was the dog. Thus the transition to the Neolithic age was not accompanied by a food-producing economy in the region. Domestic animal bones were found at early Eneolithic Caspian culture sites dating to between the middle of the $6^{\text {th }}$ and the first half of the $5^{\text {th }}$ millennium calBC. Cattle and sheep appeared in the Middle Eneolithic Khvalinskiy culture with other domestic animals, dating to the first half of the $5^{\text {th }}$ millennium calBC. Further analysis is needed to understand how the Lower Volga population learned cattle husbandry.

\section{ACKNOWLEDGEMENTS}

Special thanks to Professor Budja for the invitation to participate in Documenta Praehistorica with our article, project 33.1195.2014/K state order of Russian Ministry of Education and Science and to RFBR for support with grant No. 14-06-00041 (r). 


\section{References}

Barynkin P. P., Vasylyev I. B. 1985. Novye eneoliticheskiye pamyatniki Severnogo Prykaspya. Arkheologicheskiye pamyatniki na Evropeyskoy territorii SSSR. Voronezh: 58-75. (in Russian)

1988. Stoyanka khvalynskoy kultury Kara-Khuduk v Severnom Prikaspii. Arkheologicheskiye kultury Severnogo Prykaspiya. Samara: 123-141. (in Russian)

Barynkin P. P. 1989. Eneoliticheskiy pamyatnik Kair-Shak VI iz yuzhnoy chasti Volgo-Uralskogo mezhdurechiya. Neolit i eneolit Severnogo Prikaspiya. Samara: 106-118. (in Russian)

Bogatkina 0. G. 2010. Opredelenie kostnyh ostatkov iz II Hvalynskogo mogilnika. Hvalynskie eneoliticheskie mogil'niki i hvalynskaya eneoliticheskaya kul'tura. Samara: 400-404. (in Russian)

Driesch A. von den 1976. A Guide to the Measurement of Animals Bones from Archaeological Sites. Peabody Museum Bulletin 1. Harvard University. Harvard.

Gayduchenko L. L. 1998. Krupniy rogatiy skot eneolita stepnoy zony Kazahstana. Voprosy arheologii Kazahstana 2. Almaty - Moscow: 175-178. (in Russian)

Gasilin V. V., Kosintsev P. A. and Sablin M. V. 2008. Fauna neoliticheskoy stoyanki Varfolomeevskaya v stepnom Povolzhe. In Fauna i flora severnoy Evrazii v pozdnem kaynozoe. Ekaterinburg-Chelyabinsk: 25. 100. (in Russian)

Grechkina T. Y., Vybornov A. A. and Kutukov D. V. 2014. Novaya ranneneoliticheskaya stoyanka Baybek v Severnom Prikaspii. Samarskiy nauchnyy vestnik 3: 79-90. (in Russian)

Kozin E. V. 2004. Model' dinamiki kul'turno - demograficheskih protsessov v neolite Nizhnego Povolzhya. Istoriko-arheologicheskie izyskaniya 6: 220-229. (in Russian)

Koltsov P. M. 2004. Poseleniye Jangar. Moscow. (in Russian)

2005. Mezolit i neolit Severo-Zapadnogo Prikaspiya. Unpulished PhD thesis. Moscow. (in Russian)

Kobryn H., Lasota-Moskalewska A. 1989. Certain Osteometric Differences Between the Aurochs and Domestic Cattle. Acta Theriologica 34(4): 67-82.

Kuzmina I. E. 1988. Mlekopitayushchie Severnogo Prikaspiya. In Arheologicheskie kultury Severnogo Prikaspiya. Kuybyshev: 173-188. (in Russian)
Melentiev A. N. 1980. 0 vozniknovenii skotovodstva v evraziyskih stepyah. In Problemy epohi eneolita stepnoy $i$ lesostepnoy polosy Vostochnoy Evropy. Orenburg: 12. (in Russian)

Morgunova N. L., Vybornov A. A., Kovalyuh N. N. and Skripkin V. V. 2010. Hronologicheskoe sootnoshenie eneoliticheskih kul'tur volgo-ural'skogo regiona v svete radiouglerodnogo datirovaniya. Rossiyskaya arheologiya 4 : 18-27. (in Russian)

Naumov I. N. 2002. Hronologicheskie ramki nachal'nyh etapov rasprostraneniya domashney loshadi i navykov ee domestikatsii v Povolzhsko-Donskih stepyah. Nizhnevolzhskiy arheologicheskiy vestnik 5: 11-23. (in Russian)

2004. Neolit Povolzhsko-Donskih stepey. Unpublished $\mathrm{PhD}$ thesis. Voronezh. (in Russian)

Petrenko A. G. 2000. Sledy ritualnyh zhivotnyh $v$ mogilnikah drevnego i srednevekovogo naseleniya Srednego Povolzhya i Preduralya. Kazan. (in Russian)

Teichert M. 1975. Osteometrische Untersuchungen zur Berechnung der Widerristhöhe bei Schafen. In A. T. Clason (ed.), Archaeozoological studies. Papers of the Archaeozoological Conference. Groningen 1974. North Holland Publishing Company. Archaeozoological studies. North Holland and American Elsevier. Amsterdam and New York: 51-69.

Trifonov V. A. 2009. Sushchestvoval li na Severo-Zapadnom Kavkaze neolit? In Adaptatsiya kultur paleolita eneolita $k$ izmeneniyam prirodnoy sredy na Severo-Zapadnom Kavkaze. Saint-Petersberg: 84-93. (in Russian)

Tsalkin V. I. 1970. Drevneishie domashnie zhivotnye Vostochnoj Evropy. Moskow. (in Russian)

Yudin A. I. 2003. Hozyaystvo naseleniya orlovskoy neoliticheskoy kultury. Arheologicheskie zapiski 3: 90-96. (in Russian)

2004. Varfolomeevskaya stoyanka i neolit stepnogo Povolzhya. Saratov. (in Russian)

Vinogradov A. V. 1981. Drevnie ohotniki i rybolovy Sredneaziatskogo mezhdurechya. Moscow. (in Russian)

Vörös I. 1980. Zoological and Palaeoeconomical investigations on the archaeozoological material of the Early Neolithic Körös culture. Folia Archaeologica 31: 35-63.

Vybornov A. A. 2008. Neolit Volgo-Kamya. Samarskij gosudartvennij universitet. Samara. (in Russian) 
2010. On the correlation of natural processes in the Neolitic Volgo-Kama. Documenta Praehistorica 37: 283-287.

2011. Time and palaeoenvironment in the neolithisation of the povolzhye forest-steppe. Documenta Praehistorica 38: 267-274.

2014. Radiouglerodnoe datirovanie keramiki VolgoKamya: kriterii nadezhnosti. In A. N. Mazurkevič, M. E. Polkovnikova and E. V. Dolbunova (eds.), Archaeology of lake settlements IV-II mill. BC: Chronology of cultures, environment and palaeoclimatic rhythms. Materials of international conference dedicated the semicentennial anniversary of the researches of lake dwellings in North-Western Russia. Saint-Petersburg, 13-15 November 2014. The State Hermitage Museum, Russian academy of science. Institute for the history of material culture, Herzen State University. UMR 8215 CNRS. Trajectoires. Saint - Petersburg: 45 - 49. (in Russian)

Vybornov A., Zaitseva G., Kovaliukh N., Kulkova M., Skripkin V. and Possnert G. 2012. Chronological problems with neolithization of the Northern Caspian sea area and the forest-steppe Povolzhye region. Radiocarbon 54 (3-4): 795-799.

Vybornov A., Kulkova M., Goslar T. and Possnert G. 2013. The problem of the neolithisation process chronology in Povolzhye. Documenta Praehistorica 40: 13-20.

Vybornov A. A., Andreev K. M., Baratskov A. V., Kulkova M. A., Koltsov P. M., Yudin A. I., Dzhall T., Goslar T., Oynonen M., Possnert G. and Philippsen B. 2013. Novye dannye po radiouglerodnoy hronologii neolita lesostepnogo $\mathrm{i}$ stepnogo Povolzhya. Izvestiya Samarskogo nauchnogo tsentra Rossiyskoy akademii nauk 15(5): 254-260. (in Russian)

Vybornov A. A., Yudin A. I., Vasileva I. N., Kosintsev P. A., Kulkova M. A., Goslar T. and Doga N. S. 2015. Novye materialy neolita Nizhnego Povolzhya. Izvestiya Samarskogo nauchnogo tsentra Rossiyskoy akademii nauk 17(3). In press. (in Russian) 
